Telling About Islamic Heroes And Female Leaders

\title{
TELLING ABOUT ISLAMIC HEROES AND FEMALE LEADERS: WAYS OF IMPLANTING SELF-CONCEPT, MORAL, AND RELIGIOUS VALUE ON CHILDREN
}

\author{
Niswatin Nurul Hidayati \\ Sekolah Tinggi Agama Islam Al Hikmah Tuban, Jawa Timur, Indonesia \\ niswatinnh@gmail.com / niswatinnh@,staialhikmahtuban.ac.id
}

\begin{abstract}
The objectives of national education are realizing the fair and prosper society in term of material and spiritual based on the value of Pancasila, in which the main point is developing Indonesian citizens wholly. One of the most important components of Indonesian citizens is children, because they are the owner of the nation's future. Thus, it could be said that the implantation of self-concept, moral, and religious values should be started earlier, so that it would be strongly implanted on Indonesian children. One of the methods is storytelling with woman heroes and public figures, whether they are from Indonesia or Islamic history. The consideration in choosing the woman heroes and public figures is as a form of moral education, introducing Islamic religious values, as well as gender education on children. This becomes important because of Indonesian's social life which is full of various religions, cultures, tribes, race or ethnics, social status and others. The storytelling process as a form of learning media is expected to be applied in kindergarten (TK), Islamic Kindergarten (RA), or elementary school
\end{abstract}

Keywords: storytelling, character education, children, moral education, gender education

\begin{abstract}
Abstrak
Tujuan dari pembangunan nasional adalah untuk mewujudkan suatu masyarakat adil dan makmur yang merata baik materiil maupun spiritual berdasarkan pancasila, yang pada hakekatnya adalah pembangunan manusia Indonesia seutuhnya dan pembangunan seluruh masyarakat Indonesia. Salah satu bagian terpenting dalam komponen masyarakat Indonesia adalah anak. Karena anak adalah pemilik masa depan suatu bangsa. Oleh karena itu, dapat dikatakan bahwa penanaman konsep diri, moral, dan nilai agama harus dimulai sejak dini, sehingga akan tertanam dengan kuat pada diri setiap anak Indonesia. Salah satu cara atau media yang dapat digunakan adalah melalui proses bercerita tentang pahlawan dan tokoh perempuan, baik di lingkup Indonesia maupun dalam sejarah Islam. Pertimbangan akan pemilihan pahlawan dan tokoh perempuan sebagai bahan cerita adalah, selain sebagai bentuk pendidikan moral, pengenalan nilai Agama Islam, juga sekaligus sebagai pendidikan gender pada anak. Hal ini menjadi penting karena kehidupan sosial masyarakat Indonesia yang penuh keragaman agama, budaya, suku, ras, atau etnik, status sosial dan lainnya. Proses bercerita sebagai media pembelajaran ini diharapkan dapat diaplikasikan pada RA/TK ataupun sekolah dasar.
\end{abstract}

Vol. ㄴ. ‥ Q2. पktober 2019

Jurnal Auladuna | II 
Niswatin Nurul Hidayati

Keywords: bercerita, pendidikan karakter, anak, pendidikan moral, pendidikan gender.

\section{A. Introduction}

The aim of national development is to realize a just and prosperous society that is both materially and spiritually equitable based on Pancasila, which in essence is the complete development of Indonesian people and the development of all Indonesian people ${ }^{1}$. One of the most important parts of the Indonesian society component is children, because children are the future owners of a nation. Minister of National Education Regulation No. 58 of 2009 states that there are at least 5 aspects that must be developed in children, they are religious and moral values, language, cognition, physical-motoric and social emotional. Therefore, it can be said that the selfconcepting, moral, and religious values must begin early, so that it will be firmly embedded in every Indonesian child.

In addition to parents, educational institutions have an important role in educating the nation's generation in the process of planting self-concept, morality and religious values. National education aims to develop the potential of students to become faithful and fearful people to God Almighty, noble, healthy, knowledgeable, capable, creative, independent, and become democratic and responsible citizens (Law No. 202003 concerning the National Education System 2003, 3). However, educating a child in the modern era as it is now becoming a challenge for parents and teachers because of the gadget that presents a lot of interesting content for children. Although there are quite a lot of benefits, gadgets also have a negative side to child development, for example related to negative content that can interfere with children's moral development.

Not infrequently we also see the number of criminal cases involving children, both at elementary, junior high, or upper middle school, for example in cases of violence, brawls between lessons, sexual violence, and so on. National Commission for Child Protection states that criminal offenders from teenagers and children increase rapidly. ${ }^{2}$ Based on available data, from January to October 2009, there was an increase of $35 \%$ from the previous year. The data also shows that in these months, the number

\footnotetext{
${ }^{1}$ Muktar Latif, et al. Orientasi Baru Pendidiikan Anak Usia Dini. (Jakarta: Kencana, 2014), 1

${ }^{2}$ Kalyamandira in Hazhira Qudsyi. "Menanamkan Moral pada Anak Melalui Metode Bercerita" Psikologika: 25 - 37, 2013, 26

Jurnal Auladuna | 2

Vol. पl. No. 02. Iktober 2019
} 
of criminal cases committed by teenagers and children reached 1150, while in the previous year it only reached 713 . The cases included were murder, rape, drugs and theft. The above phenomenon is very ironic considering that children in learning and productive age are involved in criminal acts as above.

The aforementioned cases become a whip for parents and educators in schools to continue to improve themselves in the process of educating children, especially in the process of self and moral concepting in children. Providing moral education to children is not an easy matter, because morality itself is something abstract that can be difficult for children. Children have a tendency to understand concrete things because they are at that stage. However, the difficult thing does not mean it cannot be done, but only need to find the right method or method to deliver it.

Themes related to planting or moral education in children are interesting themes and have been studied by quite a number of researchers. Gunadi examined moral cultivation in early childhood through reading daily prayers and short letters in his writings entitled "Forming Characters through Moral Education in Early Childhood in the School of Raudhatul Athfal (RA) Habibillah". The research showed that the method was effectively implemented in moral learning efforts in children, where this was indicated by the day of increasing the value and percentage of each student at the research stage. ${ }^{3}$

Another research was conducted by Ibda who wrote about "Child Moral Education through Teaching Fields of PPKn and Religious Education". In his writing, he criticized the failure of moral education in Indonesia because the evaluation of learning PPKn lessons and Islamic religious education that had been carried out by teachers had not been carried out thoroughly both in terms of understanding the material (cognitive and appreciation aspects (affective aspects) and its practice (psychomotor aspects) $^{4}$

Inawati also wrote about the development of children's morality in her writing entitled "The Strategy of Moral Development and Religious Values for Early Childhood", where she mentioned that there are 11 ways or strategies that can be done

\footnotetext{
${ }^{3}$ R. Gunadi and Andi Ahmad. "Membentuk Karakter Melalui Pendidikan Moral Pada Anak Usia Dini di Sekolah Raudhatul Athfal (R.A) Habibillah. Jurnal Ilmiah Widya: 85 - 91, 2013

${ }^{4}$ Fatimah Ibda, "Pendidikan Moral Anak Melalui Pengajaran Bidang STudi PPKn dan Pendidikan Agama". Didaktika: 338 - 347, 2012.

Vol. ㅁ. No. 02. Uktober 2019 
to develop children's religious and moral values, namely (1 ) instilling a sense of love for Allah SWT, (2) creating a sense of security, (3) kissing and caressing children, (4) adding a sense of love for the homeland, (5) researching and observing, (6) touching and activating children's thinking potential, (7) giving awards, (8) physical education, (9) giving good example, (10) repetition in the learning process, and (11) meeting the needs of play. ${ }^{5}$

In addition to the above methods, the method of storytelling can also be an option to instill moral values in children, including religious values. Cameron states that storytelling is an oral activity designed not only to be heard but also to be involved in it. ${ }^{6}$ This will be very suitable for children who have a short attention span, so that children do not feel bored because they have to listen, but also get involved in the story telling process. When a child feels bored, the moral or religious values contained in the story will not be conveyed properly. Musthafa states that there are several characteristics of early age learners, they are (a) more effective if given material that is appropriate to his age; (b) prefer physical activity, (c) have an interest in what is faced and felt now (now and here), (d) have a shorter attention span than adults, and (e) implicit-acquisition learning. ${ }^{7}$

From the information above, educators or teachers can use an interesting storytelling method and involve students or their students in the story telling process, so that the learning process while playing can run, and the values contained in the story can be conveyed and internalized well. There are a lot of stories or stories that can be conveyed to children, but in this paper the authors provide recommendations for telling stories of female leaders and heroes, both in Islamic history and in Indonesia, for example Khadijah, Aisyah, Nusaybah binti Ka'ab, Lubna, Al-Malika al-Hurra Arwa al-Sulayhi, Nisaibah, Khaulah, RA Kartini, Cut Nyak Dien, and so on.

The proposal related to the giving of the female characters above is that the story will not only be a means of delivering moral messages and religious education, but will also provide gender education to children, both directly and indirectly. Their

\footnotetext{
${ }^{5}$ Asti Inawati "Strategi Pengembangan Moral dan Nilai Agama Untuk Anak Usia Dini”. Al-Athfal: 51 - 64, 2017

${ }^{6}$ L. Cameron, L. Teaching Languages to Young Learners. (Cambridge: Cambridge University Press, 2001)

${ }^{7}$ Musthafa, B. EFL for Young Leaners. (Oxford: Oxford University Press, 2003)

Jurnal Auladuna | 4

Vol. ㅁ․ No. 02. Qktober 2019
} 
stories of heroism and greatness will give children their own motivation that anyone can do great things in their lives.

\section{B. Self-Concepting, Moral, and Religious Value in Children}

In the world of education there are two types of age known, they are chronological age and biological age. Chronological age is age according to increasing age each year, while biological age is the age with increasing connections in the child's brain cells which is determined by how much stimulation that builds is given to the child. Biological age must be built seriously with accurate knowledge and implementation of education from birth to adulthood. ${ }^{8}$

Every child will pass through what we call the golden age (The Golden Ages), where the child's brain will be able to absorb many things from its environment like a sponge. At this time, it is felt to be a very appropriate time to instill self-concept, moral, and religious values to children, so that they can be internalized in the child well. Minister of National Education Regulation No. 58 of 2009 states that the level of developmental achievement describes the growth and development that children are expected to achieve in a certain age range, and the development achieved is an integration of aspects of understanding religious and moral values, physical, cognitive, language, and emotional social. ${ }^{9}$ During this time children will need help from people around them, including teachers and parents, to understand something including the development of morality. The children need help in 3 processes related to morals, namely the formation of character, personality formation (shaping or personality), and social development. ${ }^{10}$

The purpose of education is not just to educate a child to be smart in the intellectual field, but a child is also good at moral education. Moral education is an awareness to help students through knowledge, skills, attitudes, and values that contribute to individual satisfaction and social life. Moral education is said to be successful if students are able to produce moral values and behaviors that are transmitted, both verbally and behavior. Moral education aims to produce individuals who understand moral values and are

\footnotetext{
${ }^{8}$ Wismiarti. Mengapa Surga di Bawah Telapak Kaki Ibu. (Jakarta: Penerbit Airlangga Publishing, 2010), 19 20

${ }^{9}$ Latif, Muktar., Zubaidah, Rita, Zukhairina, Afandi, Muhammad. Orientasi Baru Pendidiikan Anak Usia Dini. (Jakarta: Kencana, 2013), 71 - 72

${ }^{10}$ Otib Satibi Hidayat. Metode Pengembangan Moral Dan Nilai-Nilai Agama, (Tangerang Selatan: Universitas Terbuka, 2015)

Vol. ㅁ․ No. QZ. Iktober 2019

Jurnal Auladuna| 5
} 
Niswatin Nurul Hidayati

consistent in implementing them in accordance with moral concepts taught by religion, community moral traditions, and culture. ${ }^{11}$

In moral education, to provide material related to the meaning of social life that is full of religious, cultural, ethnic, racial or ethnic diversity, social status and others, must be done appropriately and carefully. Educational experts argue that students in moral education, especially children, need orientation, meaning examples, witnesses of living values, or examples that can be seen, felt, and ultimately followed into action or behavior. ${ }^{12}$

Yusuf (2008) as quoted by Gunadi Moral development in children can take place in several ways, namely (1) direct education; through planting an understanding of right and wrong behavior or good and bad by parents, teachers, or other adults. ${ }^{13}$ The most important thing in moral education is the example of parents, teachers, or other adults in carrying out moral values, (2) Identification; that is, by imitating the appearance or moral behavior of someone who is his idol, such as parents, teachers, kiai, artists or other adults, (3) the trial and error process; that is, by developing moral behavior experimentally. Behavior that brings praise or appreciation will continue to be developed, while the behavior that brings punishment or reproach will be stopped.

\section{Storytelling as a Child Learning Method}

Learning in children always requires certain media so that what is delivered by an educator becomes interesting, considering that children have certain characteristics that are different from adults. The media comes from Latin which has an intermediary or introductory meaning. Gerlach \& Ely states that the media are human, material, or events that create conditions that make students able to gain knowledge of skills or attitudes. ${ }^{14}$ There are several types of media that are often used in Indonesia, for example 1) visual media/graphic media, namely media that can be seen for example pictures/photos, sketches, diagrams, charts/charts, graphs, cartoons, posters, maps and globes, flannel boards and bulletin boards; 2) audio media, media related to the sense of hearing; 3)

\footnotetext{
${ }^{11}$ Kirschenbaum, H., 100 Ways to Enhance Values and Morality in Schools and Youth Settings, (Boston: Allyn and Bacon, 1995), 41 - 42

${ }^{12}$ Hariyati Ceacilia, Keradus Sumaryo, dan V.P. Suparman. Pendidikan Budi Pekerti, (Grasindo: Jakarta, 2007), 6

${ }^{13}$ R. Gunadi, and Andi Ahmad. "Membentuk Karakter Melalui Pendidikan Moral Pada Anak Usia Dini di Sekolah Raudhatul Athfal (R.A) Habibillah. Jurnal Ilmiah Widya: 85 - 91, 2013

${ }^{14}$ Muktar Latif, et al. Orientasi Baru Pendidiikan Anak Usia Dini. (Jakarta: Kencana, 2014), 151

Jurnal Auladuna | 6

Vol. ㄱ. No. [2. Tktober 2019
} 
projection media (audio-visual). While Heinich and Molenda state that there are six basic types of learning media, namely: ${ }^{15}$

1. Text, is a basic element in conveying an information that has various types and forms of writing that strive to provide attraction in the delivery of information.

2. Audio media, helps convey information more memorable and helps increase the attractiveness of an offering. Types of audio include background sound, music or voice recording and others.

3. Visual media, media that can provide visual stimuli such as pictures/photographs, sketches, diagrams, charts, graphs, cartoons, posters, bulletin boards, and others.

4. Motion projection media, including motion films, bracelet films, TV programs, video cases (CD, VCD or DVD)

5. Artificial/miniature objects, including three-dimensional objects that students can touch and touch. This media is made to overcome the limitations of both objects and situations so that the learning process continues to run well.

6. Humans, including teachers, students, or experts/experts in certain fields/materials

From the explanation above, it is stated that humans are also a medium that can be used to convey certain material, in this case is a teacher or teacher. Teachers generally refer to professional educators with the main task of educating, teaching, guiding, directing, training, assessing, and evaluating students. ${ }^{16}$ Sujiono also stated that the teacher is also defined as 1) a person who has charisma or authority that needs to be emulated and emulated; 2) adults who are consciously responsible for educating, teaching and guiding children; 3) people who have the ability to design learning programs and are able to organize and manage classes; and (4) a position or profession that requires special expertise. ${ }^{17}$

When it comes to teaching moral values or religious values, the teacher can choose several methods. There are quite a number of ways or methods used to be able

15 Miranti, Ira., Engliana, dan Hapsari, Fitri Senny. Penggunaan Media Lagu Anak-Anak dalam Mengembangkan Kemampuan Kosakata Bahasa Inggris Siswa di PAUD. Faktor Jurnal Ilmiah Kependidikan Volume II Nomor 2, 2015, 169

${ }^{16}$ Muktar Latif, et al. Orientasi Baru Pendidiikan Anak Usia Dini. (Jakarta: Kencana, 2014), 245

${ }^{17}$ Muktar Latif, et al. Orientasi Baru Pendidiikan Anak Usia Dini. (Jakarta: Kencana, 2014), 245 Vol. ㅁ․ No. Q2. पktober 2019 
to teach moral values or religious values to children, for example through teaching daily prayers, such as that done by Gunadi who examines moral cultivation in early childhood through reading Daily prayers and short letters in his writings entitled "Forming Character through Moral Education in Early Childhood at Raudhatul Athfal School (RA) Habibillah". However, in this paper, the writer focuses on proposals related to the storytelling method. ${ }^{18}$

Derni states that storytelling is telling something that tells about an action or event and is delivered orally with the aim of sharing experiences and knowledge with others. ${ }^{19}$ Storytelling is also interpreted as a way of telling and telling a story or giving an explanation orally. The contents of the story sought related to: a) The world of children's lives full of joy, which requires the contents of the story to have elements that can provide feelings of joy, funny, interesting, and exciting for children; b) adjusted to the interests of children who are usually concerned with animals, plants, vehicles, dolls, robots, planets, etc. c) the level of age, needs and ability of children to capture the story is different. It is hoped that it must be concise or short in the child's attention span; d) opens opportunities for children to ask questions and respond after the teacher has finished telling stories. ${ }^{20}$

Ghazi in his article mentioned that there are quite a lot of benefits from telling stories to children, they are: ${ }^{21}$

1. Make it easier for children to learn languages

2. Quality stories will shape the child's personality

3. Foster creativity

4. Improve children's thinking power

5. Creating a child's imagination

6. An easy way to introduce Islamic values to children

7. Keep children away from TV, gadgets, games and the like

8. As a means to build intimacy between children and parents

${ }^{18}$ Gunadi, R. Andi Ahmad. "Membentuk Karakter Melalui Pendidikan Moral Pada Anak Usia Dini di Sekolah Raudhatul Athfal (R.A) Habibillah. Jurnal Ilmiah Widya: 85 - 91, 2013

${ }^{19}$ Hazhira Qudsyi. "Menanamkan Moral pada Anak Melalui Metode Bercerita" Psikologika: 25 - 37, 2013, 28

${ }^{20}$ Muktar Latif, et al. Orientasi Baru Pendidiikan Anak Usia Dini. (Jakarta: Kencana, 2014), 111

21 Ghazi, Ummu. Manfaat Bercerita untuk anak https://www.elmina.id/manfaat-bercerita-untuk-anak/ accessed on 10 August 2018

Jurnal Auladuna $\mid 8$

Vol. ㅁ. No. 02. 0ktober 2019 
9. Adding parental insight

10. Foster a culture of reading and love of science from an early age

In his writings, Hanum Savira also added several benefits and aims to tell children, namely:

1. Able to instill the values of honesty, courage, friendliness, sincerity, and positive life

2. Providing social knowledge, moral and religious values

3. Providing experience for learning to listen

4. Provide information about the social life of children with people around them

5. Helping children develop various roles that a child may have.

Of the several benefits of storytelling above, it is clearly stated that storytelling can foster good values to children, for example honesty, courage, friendliness, sincerity, and positive life. Ghazi also mentions that storytelling can be used as a way to teach Islamic values to children. ${ }^{22}$ But then, what needs to be noticed is that children have different phases regarding their ability to absorb something. Thus, the selection of stories must be adjusted to the age of the child, whether the child is in kindergarten / RA age or at elementary school age. There are several age phases that determine the suitability of the story and the child's age, they are: ${ }^{23}$

a. Children aged 3 to 5 years really like stories and listen to stories attentively. At this age children have a high imagination but still limited to the surrounding environment, meaning that the child will imagine something that is within the scope of his environment.

b. Children aged 6 to 9 years have high imagination, far beyond the environment that surrounds the child. In this phase the child is very fond of imaginary stories. Stories that are useful for children are taking children away from the limits of their knowledge without leaving reality.

${ }^{22}$ Ghazi, Ummu. Manfaat Bercerita untuk anak https://www.elmina.id/manfaat-bercerita-untuk-anak/ accessed on 10 August 2018

${ }^{23}$ Fitri Rayani Siregar. "Dongeng dalam Pengajaran Bahasa Inggris terhadap Anak Sekolah Dasar". Logaritma: 19 - 30, 2013, 22 - 23

Vol. ㅁ․ No. QZ. Iktober 2019

Jurnal Auladuna | 9 
Niswatin Nurul Hidayati

c. Children aged 9 to 12 years no longer like to imagine as much as the previous phase. At this age children pay more attention to life and already have a few principles and values. They love the stories of heroism and adventure. But this does not mean that their fantasy period has ended.

Children also have certain characteristics that educators need to pay attention to, so that what is conveyed is not the wrong target later. There are 10 characteristics of young learners, they are: $:^{24}$

a. Children aged 5-7 years still have an egocentric attitude, this attitude still wants to win themselves, those who like to connect what they learn or do with themselves.

b. Children aged 5-7 years still find it difficult to distinguish between concrete and abstract.

c. Imaginative and active

d. Learners easily feel bored

e. Colorful and fun young learners

f. Younger group still has a self-centered nature until the age of 7 years.

g. Children at this elementary age love stories

h. In the age of 8-10 years young learners already have a readiness in the language, they already understand the context of the essence of a conversation without having to understand the meaning of word for word

i. Young learners love conversations to interact and talk about what they have

j. Young learners are active learners. They like learning by learning by doing.

\section{Stories of Female Figures and Heroes}

Indonesia has several female heroes or figures that can be used as material to tell children, for example Cut Nyak Dien, Cut Nyak Mutia, R.A. Kartini, and so on. In Islam, there are quite a number of great female figures that can be shared with children, although there are likely to be some strangers to us, such as Khadijah, Ayesha, Nusaybah bint Ka'ab, Lubna, Al-Malika al-Hurra Arwa al-Sulayhi, Nisaibah, and Khaulah.

${ }^{24}$ Suyanto, Kasihani K.E., English for Young Learners, (Jakarta: Bumi Aksara, 2006), 15 Jurnal Auladuna | 10

Vol. I. No. [2. Dktober 2019 
1. Khadijah, Khadijah was a respected elite merchant in Mecca. In the course of Islam, Khadijah was the earliest person and woman to convert to Islam. The Messenger of Allah said "God Almighty in this life could not give anyone better than him (Khadijah), he accepted me when some people rejected me, he trusted me when people doubted me, he was like a treasure with me when some people forbid it and God gave only children through him. "

2. Aisha, is a Muslim woman figure that is widely told where she has narrated a lot of the hadith of the Prophet Muhammad. Ayesha was also known for her thoughts in many matters relating to students, schools, politics and the role of women who at that time were still controversial. Ayesha had also been involved in the Basra war.

3. Al-Malika al-Hurra Arwa al-Sulayhi, if we only assume that only men have the capability to lead, then we can look at the story of Arwa. Arwa is an Islamic woman who is known to be very intelligent and has a leader spirit. She is a queen of Islam in the kingdom of Yemen. During his leadership, he was known to be highly admired and had a strong influence on the development of Islam in the Fatimid Caliphate period. She was widely mentioned in the Friday sermon at the time and was the first Muslim woman to obtain the highest rank in the Fatimid Caliphate.

4. Nusaibah, he has the title Ummu Umarah. He is said to have been a swordsman who defended Rasulullah in the Battle of Uhud. Said the Prophet sallallaahu alaihi Wassalam later, "I will not look to the right and left at the battle of Uhud unless I see Nusaibah bint Ka'ab fight to defend me." martyred in the way of Allah. Nusaibah was one of two women who joined 70 Ansar men who took their allegiance to the Prophet sallallaahu alaihi Wassalam. In the second altar of Aqabah she was accompanied by her husband Zaid bin Ahsim and two of his sons:

5. Khaulah, Since childhood likes and is good at playing swords and spears, and continues to practice until it is time to use his skills to defend Islam with other mujahidah. It is narrated how in one of the battles against the Roman pagan forces under the leadership of Commander Khalid bin Walid, suddenly there appeared a rider in a black clad who swiftly spurred his horse into the middle of the battlefield. Like a hungry lion ready to pounce, the horsed figure shook his sword and in a short time brought down three enemies. Commander Khalid bin Walid and his entire army were astonished at the dexterity of the figure in the black shirt. They wondered who was the warrior who 
had his whole body closed and only his eyes were visible. The spirit of the jihad of Muslim troops was burned again upon learning that the Black Rider, in the rider on the black shirt was a woman! Khaulah's courage was tested when he and several Mujahideen were captured by the enemy in the battle of Sahura.

\section{E. Ways of Story Telling the Teacher Can Do}

Latif et al. states that there are several ways in which a teacher can tell a story, they are: ${ }^{25}$

a) Read directly from a story book. There are several things that need to be considered when the teacher chooses this technique, they are: a) choose books with pictures that are harmonious and not conspicuous in the eyes; b) choose books with large writing with sentences that are not too long and use good and correct Indonesian; c) choose the contents of the story raised from special things in the area where children live; d) fill in the story with repeated words on each page is also good and interesting, especially for the process of reading and writing; e) when reading a story, the position of the book held by the teacher must be visible to all children; and f) start introducing knowledge about books.

b) Telling stories. Storytelling is a way of telling stories that carry on cultural heritage from one generation to the next.

c) Tell a story by using a picture illustration from a book

d) Tell stories using a flannel board

e) Storytelling using puppet media

f) Tell stories by using or playing fingers

\section{F. Conclusion}

Teaching religious and moral values in children is very important, because at that time children absorb many things from the surrounding environment. Therefore, by giving moral lessons will help children in the future who are our nation's heirs. There are many methods that can be used to teach moral values to children, but the method of storytelling is considered to be a very good method to use.

${ }^{25}$ Muktar Latif, et al. Orientasi Baru Pendidiikan Anak Usia Dini. (Jakarta: Kencana, 2014), $111-112$

Jurnal Auladuna | 12

Vol. ㄱ. No. 02. Oktober 2019 
The method of storytelling has many benefits, for example enriching children's language vocabulary, increasing their imagination, and of course being a powerful way to instill good values in children. Of course, the process of storytelling is carried out with certain techniques and not just storytelling given that one of the characteristics of a child is having a short concentration of power. The use of media, such as hand puppets, video, audio or others can be used so that children do not get bored quickly when listening. Using books with lots of pictures and illustrations can also be selected.

The choice of stories that can be used in the process of instilling moral values in children is indeed diverse, but by choosing female figures in Islam or Indonesian female heroes, religious values will be embedded in children, and education on gender equality will also be included. in it, both directly and indirectly, where every child will realize that they can all do things that are useful to many people and do great things, including girls. This is like the stories mentioned in the previous section.

\section{REFERENCES}

Cameron, L. 2001. Teaching Languages to Young Learners. Cambridge: Cambridge University Press.

Departemen Pendidikan Nasional. 2003. Undang-undang Sistem Pendidikan Nasional Nomor 20. Departemen Pendidikan Nasional. Jakarta

Ghazi, Ummu. 2017. Manfaat Bercerita untuk anak https://www.elmina.id/manfaatbercerita-untuk-anak/accessed on 10 August 2018

Gunadi, R. Andi Ahmad. 2013. "Membentuk Karakter Melalui Pendidikan Moral Pada Anak Usia Dini di Sekolah Raudhatul Athfal (R.A) Habibillah. Jurnal Ilmiah Widya: $85-91$

Hariyati Ceacilia, Keradus Sumaryo, dan V.P. Suparman. 2007. Pendidikan Budi Pekerti, Grasindo, Jakarta

Hidayat, Otib Satibi, 2015. Metode Pengembangan Moral Dan Nilai-Nilai Agama, Tangerang Selatan: Universitas Terbuka

Ibda, Fatimah. 2012. "Pendidikan Moral Anak Melalui Pengajaran Bidang STudi PPKn dan Pendidikan Agama”. Didaktika: 338 - 347

Vol. I. No. Q2. Iktober 2019

Jurnal Auladuna | 
Inawati, Asti. 2017. "Strategi Pengembangan Moral dan Nilai Agama Untuk Anak Usia Dini”. Al-Athfal: $51-64$

Kirschenbaum, H., 1995. 100 Ways to Enhance Values and Morality in Schools and Youth Settings, Boston: Allyn and Bacon.

Latif, Muktar., Zubaidah, Rita, Zukhairina, Afandi, Muhammad. 2014. Orientasi Baru Pendidiikan Anak Usia Dini. Jakarta: Kencana

Miranti, Ira., Engliana, dan Hapsari, Fitri Senny. 2015. Penggunaan Media Lagu Anak-Anak dalam Mengembangkan Kemampuan Kosakata Bahasa Inggris Siswa di PAUD. Faktor Jurnal Ilmiah Kependidikan Volume II Nomor 2, 2015

Musthafa, B. 2003. EFL for Young Leaners. Oxford: Oxford University Press.

Para "Jagoan Wanita" di Zaman Rasulullah https://naungancinta.wordpress.com/2008/03/24/para- $\%$ E2\%80\%9Cjagoanwanita $\% \mathrm{E} 2 \% 80 \% 9 \mathrm{D}$-di-zaman-rasulullah-saw/accessed on 20 August 2018

Qudsyi, Hazhira. 2013. "Menanamkan Moral pada Anak Melalui Metode Bercerita" Psikologika: 25 - 37

Savira, Hanum. Manfaat dan Tujuan Bercerita pada Anak Usia Dini https://www.kompasiana.com/hanumsavira/59c09f1b666c1413691cf4c2/manfaat -dan-tujuan-bercerita-pada-anak-usia-dini accessed on 10 August 2018

Siregar, Fitri Rayani. 2013. "Dongeng dalam Pengajaran Bahasa Inggris terhadap Anak Sekolah Dasar". Logaritma: 19 - 30

Suyanto, Kasihani K.E., 2006. English for Young Learners, Jakarta: Bumi Aksara

Tokoh dalam Histori Islam http://duta-cherbond.blogspot.com/2015/03/10-tokohdalam-history-islam.html accessed on 10 August 2018

Wismiarti.2010. Mengapa Surga di Bawah Telapak Kaki Ibu. Jakarta: Penerbit Airlangga Publishing. 